\title{
Örgütsel Bağıııı̆ın Örgütsel Özdeşleşmeye Etkisinde İşten Ayrılma Niyetinin Rolünün Yapısal Eşitlik Modeli ile Analizi
}

The Analysis of the Role of Intention to Leave in the Effect of Organizational Commitment on the Organizational Identification with the Structural Equation Modeling

\section{Dr. Öğr. Üyesi Halil Özcan ÖZDEMiR ${ }^{1}$ - Yusuf Ziya iSMAiLÇEBiं}

Başvuru Tarihi: 23.12.2019

Kabul Tarihi: 06.03.2020

Makale Türü: Araştırma Makalesi

Öz

Bu çalışmanın amacı çalışanların örgütsel bağlılık ve örgütsel özdeşleşme düzeyleri ile işten ayrilma niyetleri arasındaki ilişkileri incelemektir. Bu kapsamda Kayseri ili organize sanayi bölgesinde faaliyette bulunan işletmelerdeki çalışanlar araştırmanın anakitlesini oluşturmaktadır. Araştırmanın örneklemini 232 özel sektör çalışanı oluşturmaktadır. Bu doğrultuda nicel araştırma yöntemlerinden ilişkisel tarama yönteminde yürütülen çalışmada yapısal eşitlik modellemesinden yararlanılmıştır. Araştırma sonuçları SPSS 22.0 ve Lisrel 8.8 programları yardımı ile analiz edilmiştir. Araştırma sonuçlarına göre; çalışanların örgütsel özdeşleşme düzeylerinin çalışanların işten ayrlma niyetleri üzerinde doğrudan bir etkisinin olmadığı, çalışanların örgütsel bağlılıkları (aracı değişken) üzerinden bir etkisinin bulunduğu belirlenmiştir.

Anahtar Kelimeler: Örgütsel Bağlllık, Örgütsel Özdeşleşme, Işten Ayrılma Niyeti, Yapısal Eşitlik Modeli

\begin{abstract}
The aim of this study is to investigate role of intention to leave in the effect of organizational commitment on the organizational identification with the structural equation modeling. In this context, the employees in the enterprises operating in the organized industrial zone of Kayseri are taken as examples. The sample of the study consists of 232 private sector employees. In this direction, the structural equation modeling has been utilized in the study carried out in relational screening method, one of the quantitative research methods. The results of the research were analyzed with the help of SPSS 22.0 and Lisrel 8.8. According to the results of the research, it was found that the organizational identification levels of the employees did not have a direct effect on the employees' intention to quit, and they had an effect on the organizational commitment (mediator variable) of the employees.
\end{abstract}

Keywords: Organizational Commitment, Organizational Identification, Intention to Leave, Structural Equation Modeling

\footnotetext{
${ }^{1}$ Kırșehir Ahi Evran Üniversitesi Ziraat ve Tarım Fakültesi, hoozdemir@ahievran.edu.tr, ORCID: 0000000200213618

${ }^{2}$ Akbank Personeli, yusuziya.cebi@hotmail.com, ORCID: 0000000173880342
} 


\section{Giriş}

Günümüz koşullarının getirdiği zorlu şartlar toplumları ve çalışma koşullarını etkilemektedir. Çalışma koşullarını ve dolaylı olarak çalışanları etkileyen faktörler neticesinde insan kaynaklarının etkili ve verimli kullanımı daha önemli hale gelmiştir. Çalıştığı örgüte bağlılık duymayan ya da çalıştığı örgüt ile kendini özdeşleştirmeyen çalışanlarda sinizm ve işten ayrılma gibi olumsuz davranışlar gözlemlenebilmektedir. Bu gibi olumsuz sonuçlanabilecek olayların önceden tespit edilerek gerekli önlemlerin alınması karlılık ve verimlilik artışı gibi faktörleri de beraberinde getirebilecektir. Bu çalışma ile üretim faktörlerinden olan insan kaynaklarının çalıştıkları örgütlerine bağlılıkları, o örgütle kendilerini özleştirmeleri ve işten ayrılma niyetleri faktörleri arasındaki ilişkiyi ortaya koymak ve çözüm önerileri geliştirmek amaçlanmaktadır. $\mathrm{Bu}$ çalışma kapsamında öncelikle örgütsel bağllık, örgütsel özdeşleşme ve işten ayrılma kavramları tanımlanmış daha sonra bu kavramlar arasındaki ilişkilere yönelik yapılmış çalışmalar incelenmiştir. Yöntem kısmında araştırmanın modeli, örneklemi ve kullanılan ölçeklere yer verilmiştir. Sonraki bölümde ise bulgular ve sonuçları açıklanarak sonuç ve öneriler kısmı ile çalışma tamamlanmıştır. Bu çalışma örgütsel davranış alanındaki çalışanlare, yöneticilere ve araştırmacılara önemli katkılar sağlayacak orijinal bir çalışmadır.

\section{Örgütsel Bağlılık}

Örgütsel bağlılık çalışanın örgüte olan psikolojik yaklaşımını ifade etmekte ve işgören ile örgüt arasındaki ilişkiyi yansıtan, örgüt üyeliğini devam ettirme kararına yol açan psikolojik bir durum olarak tanımlanmaktadır (Meyer ve Allen, 1991). Örgütsel bağlılık; işi bırakma, işe devamsızlık, işten geri geri çekilme ve iş arama faaliyetleri ile iş doyumu, işe sarılma, moral ve performans yapılarla; özerklik, sorumluluk, katılım, görev anlayışı gibi çalışanın işi ve rolüne ilişkin özelliklerle; yaş, cinsiyet, hizmet süresi ve eğitim gibi çalışanların kişisel özellikleriyle ve bireylerin sahip olduğu örgütsel bağlılık kestiricilerini bilmeyle yakından ilişkilidir (Balay, 2000, s. 1). Örgütsel bağlılık, bir işletmenin sahip olduğu değerlere ve hedeflere uyumlu davranışlar sergileyen bir çalışanın, iş hayatındaki bir grubun parçası olduğu kadar sosyal bir topluluğun da parçası olması anlamını taşımaktadır. Örgütsel bağlılık kavramı, çalışanlar için aidiyet duygularının oldukça güçlü olmasını sağlayan, pekiştirici bir unsurdur (Demirel, 2008, s. 183). Örgüte bağlılık türlerini Çetin (2004) duygusal bağlılık, devam bağlılığı ve zorunluluk (normatif) bağlılık şeklinde 3 kısma ayırmıştır.

\section{Duygusal Bă̆lılık:}

Duygusal bağlılık boyutunda, çalışan örgütün değerlerini kabul eder ve o örgütün bir parçası olarak devam etmeyi ister. Bu tür çalışanlar her yöneticinin veya işverenin arzu ettiği işine sadık çalışan çeşididir (Balay, 2000). Genel olarak söylemek gerekirse örgütüne duygusal anlamda bağlı olan çalışanlar bu sınıfta değerlendirilmektedir.

\section{Devam Bağhllı̆̆l:}

Devam bağlılı̆̆ı kavramı, çalışanın örgütten ayrılmasının maliyetlerini göz önünde bulundurması ile ilgilidir. Meyer ve Allen'a göre (1991) çalışanların örgüte bağlılık duymalarının ve örgütte kalmak istemelerinin temel nedeni, örgütte kalmaya ihtiyaç duymalarıdır. Çalışanlarde devam bağlılığının oluşmasına neden olan birtakım bireysel ve 
örgütsel faktörler bulunmaktadır. Devam bağlılığını etkileyen bu faktörler şu şekilde özetlenebilecektir. Çalışanın çalıştığı örgütte zaman içerisinde kazandığ örgütlere transfer edebileceğine dönük endişe, çalışanın iş değiştirmesi durumunda farklı bir yerleşim yerine taşınmak istememesi durumu, çalışanın örgütten ayrılması durumunda tazminat veya prim gibi kazanımlarını kaybedeceği korkusu, çalışanın yaşının ilerlemiş olması vb. gibi nedenler çalışanda devam bağlılığının oluşmasına neden olan faktörlerdir (Allen ve Meyer, 1990, s. 18).

\section{Zorunluluk Bă̆lllı̆ğ:}

Normatif bağlılık olarak da adlandırılan bu bağlılık çalışanların bir minnettarlık duygusu sonucu örgütte kalmaları durumunu ifade eder. İşverenlerin gerçekten işe çok ihtiyaçları olduğu bir zamanda çalışanları işe alması sonucunda ortaya çıkan işverenleriyle kalmalarının en doğru şey olacağı yolundaki değer yargılarına sahip olmaları zorunluluk bağlılı̆̆ şeklinde tanımlanabilir. Çalışanlar, örgütün kendilerine iyi davrandığını ve bundan dolayı da kendilerinin örgütte bir süre çalışmalarının örgüte karşı borçları olduğu kanısındadırlar (Balay, 2000).

\section{Örgütsel Özdeşleşme}

Örgütsel özdeşleşme; çalışanlarda bireysel ve örgütsel değerlerin örtüşmesiyle birey ve örgüt arasında birliktelik ve aidiyet algısının oluşması ya da bireyin kendisini tanımlamasında bir örgütün üyesiymiş gibi algıladığı süreç olarak tanımlanmaktadır (Riketta, 2005, s. 360). Örgütsel özdeşleşme, çağdaş örgütsel davranış yazınında önemsenen ve ilgi çeken bir kavramdır. Örgütsel özdeşleşme, çalışanlar ve örgüt arasında var olan psikolojik ilişkiyi yansıtmakta ve çalışma ortamındaki birçok önemli tutum ve davranışı açıklamaktadır (Edwards, 2005, s. 207). Örgütsel özdeşleşme ile örgütsel bağlllık kavramı birbirleri ile karıştırılan bir kavramdır. Örgütsel özdeşleşme psikolojik ve bilişsel bir süreç iken; örgütsel bağlılık, çalışanların örgütlerine bağlılıkları ve örgütün bir parçası olma yönündeki davranış odaklı bir tutumdur (Ketchand ve Strawser, 2001). Mael ve Ashforth (1995) örgütsel özdeşleşme kavramını özel bir kavram olarak ifade etmiş, örgütsel bağlılığı birey ile örgüt arasındaki sosyal takas olarak nitelendirmişlerdir.

\section{İşten Ayrılma Niyeti}

Literatürde işten ayrılma niyeti için yapılan tanımların benzerlikleri dikkati çekmektedir. İşten ayrılma niyeti, işten ayrılma davranışından farklıdır. İşten ayrılma niyeti, çalışanın işten ayrılmasını ifade etmez, uygun ortam sağlandığında işyerinden ayrılabileceğini ifade etmektedir. İşten ayrılma niyeti, ayrılmak gibi fiiliyata dönüşmese bile personelin iş yerindeki yaşantısını etkileyebilmektedir (Ünlüsoy Dinçer, 2010, s. 49). İş yerindeki stres, iş tatminsizliği, çalışanın çalıştığı örgütüne karşı güvensizlik, düşük seviyedeki örgütsel bağlılık, verimlilikte düşüş gibi faktörler işten ayrılma eğilimlerine yol açabilmektedir (Schweiger ve Denisi, 1991).

\section{Örgütsel Bağllıık, Örgütsel Özdeşleşme ve İşten Ayrılma Niyeti Arasındaki ilişkiler}

Literatürdeki örgütsel bağlılık, örgütsel özdeşleşme ve işten ayrılma niyetine yönelik çalışmalar incelenmiştir. Cole ve Bruch (2006) 10948 çalışanı olan büyük bir çelik fabrikasında yaptıkları 
araştırma sonucunda; örgütsel bağllığa ilişkin algıların çalışanların işten ayrılma niyetlerini kurum içerisindeki hiyerarşilerine bağlı olarak etkileyebileceğini belirtmişlerdir. Sökmen ve Şimşek (2016) Ankara ilinde kamu kurumunda uzmanlarla yapmış oldukları çalışmada örgütsel bağlılığın örgütsel özdeşleşme üzerinde anlamlı bir etkisinin olduğunu; işten ayrılma niyeti üzerinde ise negatif yönlü bir etkisinin olduğunu belirlemişlerdir. Tuna ve Yeşiltaş (2014) Ankara ve Antalya'daki 5 yıldızlı otel işletmelerinde çalışanlar üzerine yapmış oldukları çalışmada örgütsel özdeşleşme ile işten ayrılma niyeti üzerinde negatif yönlü bir ilişki tespit etmişlerdir. Akyüz ve Yılmaz (2015) yapmış oldukları çalışmada örgütsel özdeşleşmenin işten ayrılma niyetini negatif yönde anlamlı bir şekilde etkilediğini tespit etmişlerdir. Tolukan, Şahin ve Koç (2016) jimnastik antrenörlerinin örgütsel özdeşleşme düzeyleri ile işten ayrılma niyetleri arasındaki ilişkiye yönelik yaptıkları çalışma sonucunda örgütsel özdeşleşme ile işten ayrılma niyeti arasında orta düzeyde negatif yönlü bir ilişki bulmuşlardır. Öktem, Kızıltan ve Tarhan (2016) ise otel çalışanları üzerine yaptıkları çalışma sonucunda; örgütsel özdeşleme ile işten ayrılma niyeti arasında beklenenden farklı olarak pozitif yönlü bir ilişki bulmuşlar ve bu durumu çalışanların daha iyi otellerde çalışma isteklerine bağlamışlardır.

\section{Yöntem}

\section{Araştırmanın Modeli}

Bu çalışmanın, Kayseri ili organize sanayi bölgesinde faaliyette bulunan orta ve büyük ölçekli işletmelerdeki çalışanların örgütsel bağlılık, örgütsel özdeşleşme ve işten ayrılma niyetleri arasındaki ilişkinin ortaya konulması amaçlanmıştır. Bu doğrultuda nicel araştırma yöntemlerinden ilişkisel tarama yöntemiyle yürütülen çalışmada yapısal eşitlik modellemesinden yararlanılmıştır. İlişkisel tarama modeli; “iki veya daha fazla sayıda değişken arasında ilişkinin olup olmadığını ve/veya ne düzeyde ilişki olduğunu belirlemeyi amaçlayan araştırma modeli” olarak tanımlanmaktadır (Karasar, 2003). Korelasyonel araştırma olarak da isimlendirilen ilişkisel tarama modellerinden amaç, değişkenler arasındaki ilişkileri açıklamak ve sonuçları tahmin etmektir (Fraenkel, Wallen, and Hyun, 2012). Araştırma kapsamında oluşturulan hipotezler şu şekildedir:

$\mathrm{H}_{0}=$ Çalışanların örgütsel bağlılık, örgütsel özdeşleşme ve işten ayrılma niyetleri arasında bir ilişki yoktur.

$\mathrm{H}_{1}=$ Çalışanların örgütsel bağlılık, örgütsel özdeşleşme ve işten ayrılma niyetleri arasında bir ilişki vardır.

$\mathrm{Bu}$ araştırma kapsamında Kayseri ili organize sanayi bölgesinde faaliyette bulunan işletmelerdeki çalışanların örgütsel bağlılık, örgütsel özdeşleşme ve işten ayrılma düzeyleri arasında kurulan ilişki modeli Şekil 1'de gösterilmiştir. 


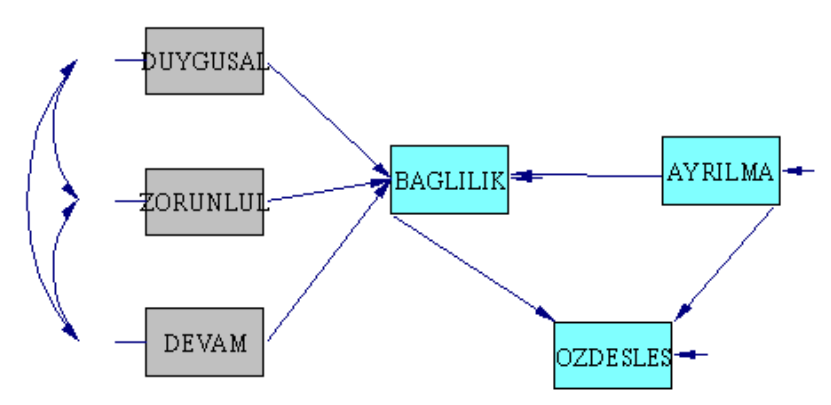

Şekil 1. Özel Sektör çalışanlarının örgütsel bağlılık, örgütsel özdeşleşme ve işten ayrılma niyetleri arasındaki ilişkilere yönelik kurulan yapısal eşitlik modellemesi

Araştırma kapsamında Kayseri ili organize sanayi bölgesinde faaliyette bulunan işletmelerdeki çalışanların örgütsel bağl1lık düzeyleri; duygusal, zorunluluk ve devam bağll1ığı olmak üzere üç boyutta belirlenmiştir. Bu boyutların örgütsel bağlılığı ne düzeyde açıkladığının belirlenmesi amacıyla öncelikle Şekil 2'de gösterilen ölçme modeli kurulmuştur. Ardından her biri tek boyutlu olan örgütsel özdeşleşme ve işten ayrilma niyetlerinin dâhil edildiği Şekil 3’te görülen yapısal model oluşturulmuştur.

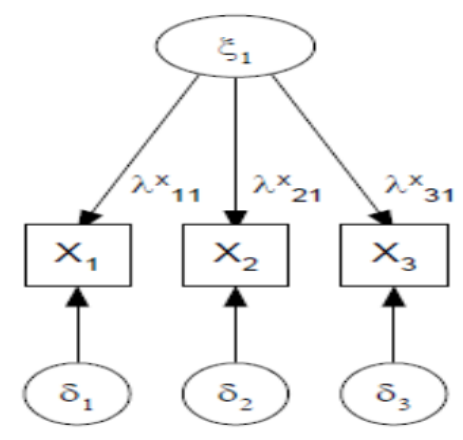

Şekil 1. Ölçme Modeli

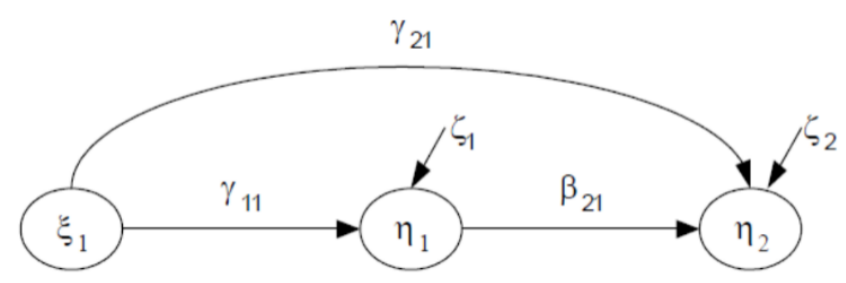

Şekil 3. Yapısal Model

\section{Katılımcılar}

Araştırma kapsamında Kayseri ili organize sanayi bölgesinde faaliyette bulunan işletmelerdeki çalışanlardan amaçlı örnekleme yöntemlerinden kolay ulaşılabilir örnekleme yöntemine dayalı olarak 232 kişiye ulaşılmıştır. Uygulama öncesinde gerekli izinler alınmıştır. Katılımcıların \%56,0'sını (n=130) kadın, \%44,0'ünü (n=102) erkek çalışanlar oluşturmaktadır. Çalışanların \%52,6’sı $(\mathrm{n}=122)$ evli, \%47,4’ü $(\mathrm{n}=110)$ bekardır. Çalışanların eğitim düzeylerine göre 
dağılımları incelenmiş, araştırmaya katılan çalışanların \%22,0’sı ( $\mathrm{n}=51)$ lise, \%44,8'inin ( $\mathrm{n}=104)$ ön lisans, \%25,4'ünün ( $n=59)$ lisans, \%7,8’inin $(n=18)$ lisansüstü mezunu olduğu tespit edilmiştir. Katılımcıların mesleki kıdemlerinin 1 yıl ile 38 yıl arasında değişiklik gösterdiği, ortalama kıdem sürelerinin 8,36 yıl $( \pm 7,59)$ olduğu belirlenmiştir. Çalışanların yaşlarının 18 ile 63 arasında değiştiği, ortalama yaşlarının 32,05 $( \pm 10,11)$ olduğu tespit edilmiştir.

\section{Veri Toplama Araçları}

Bu araştırmanın verileri "Örgütsel Bağlılık Ölçeği”, "Örgütsel Özdeşleşme Ölçeği” ve "İşten Ayrılma Niyeti Ölçeği” ile toplanmıştır.

\section{Örgütsel Bă̆lllık Ölçeği}

Araştırmada Kayseri ili organize sanayi bölgesinde faaliyette bulunan işletmelerdeki çalışanların örgütsel bağlılık düzeylerini saptamak amacıyla Allen ve Meyer (1990) tarafından geliştirilen Çınar (2015) Türkçeye uyarlanan Örgütsel Bağlılık Ölçeği kullanılmıştır. Ölçekte duygusal, devam ve zorunluluk bağlılığı olmak üzere üç boyutta toplanan 18 madde yer almaktadır. Maddelerin cevapları 5'li Likert tipinde derecelendirilmiştir. 1-Kesinlikle Katılmıyorum, 5-Kesinlikle Katılıyorum ifadesine karşılık gelmektedir. Çınar (2015), ölçekte yer alan maddelere katılımcıların vermiş oldukları cevaplar doğrultusunda hesaplanan iç tutarlılık Cronbach alfa güvenirlik katsayısı 0,851 olarak hesaplanmıştır (Çınar, 2015).

$\mathrm{Bu}$ araştırma kapsamında çalışanların diğer değişkenlerle örgütsel bağlılıkları arasındaki ilişkilerin tespit edilmesi amacıyla öncelikle bir ölçme modeli oluşturulmuştur. Ölçme modelinin hesaplanan uyum değerleri Tablo 1'de görülmektedir.

\section{Tablo 1. Örgütsel Bă̆lılık Ölçeğine İlişkin Ölçme Modeline Ait Uyum İndeks Değerleri}

\begin{tabular}{ccccc}
\hline $\begin{array}{c}\text { Uyum } \\
\text { Indeks }\end{array}$ & $\begin{array}{c}\text { Oluşturulan } \\
\text { Model Değerleri }\end{array}$ & $\begin{array}{c}\text { Mükemmel Uyum } \\
\text { Kriterleri }\end{array}$ & $\begin{array}{c}\text { Kabul Edilebilir Uyum } \\
\text { Kriterleri }\end{array}$ & Değerlendirme \\
\hline$\chi^{2 /(\mathrm{df})}$ & $\begin{array}{c}481,62(132) \\
=3,65\end{array}$ & $0 \leq \chi^{2} \leq 3$ & $3<\chi^{2} \leq 5$ & Kabul edilebilir uyum \\
RMSEA & 0,080 & $0 \leq \mathrm{RMSEA} \leq 0,05$ & $0,05<\mathrm{RMSEA} \leq 0,08$ & Kabul edilebilir uyum \\
CFI & 0,95 & $0,97 \leq \mathrm{CFI} \leq 1,00$ & $0,95 \leq \mathrm{CFI}<0,97$ & Kabul edilebilir uyum \\
NFI & 0,90 & $0,95 \leq \mathrm{NFI} \leq 1,00$ & $0,90 \leq \mathrm{NFI}<0,95$ & Kabul edilebilir uyum \\
AGFI & 0,85 & $0,90 \leq \mathrm{AGFI} \leq 1,00$ & $0,85 \leq \mathrm{AGFI}<0,90$ & Kabul edilebilir uyum \\
GFI & 0,91 & $0,95 \leq \mathrm{GFI} \leq 1,00$ & $0,90 \leq \mathrm{GFI}<0,95$ & Kabul edilebilir uyum \\
\hline
\end{tabular}

Tablo-1'de yer alan bilgiler incelendiğinde çalışanların örgütsel bağlılık düzeylerinin üç boyutlu 18 maddelik modelinin hesaplanan model-veri uyum değerleri doğrultusunda ( $\chi^{2} /(\mathrm{df})$, RMSEA, CFI, NFI, AGFI ve GFI) kabul edilebilir değerlerde olduğu tespit edilmiştir (Schermelleh-Engel, Moosbrugger, Müller, 2003). Ayrıca özel sektör çalışanlarının ölçek maddelerine vermiş oldukları cevapların Cronbach alfa güvenirlik katsayısı 0,776 olarak hesaplanmıştır. Hesaplanan değerler Kayseri ili organize sanayi bölgesinde faaliyette bulunan işletmelerdeki çalışanların örgütsel bağlılık ölçeğindeki maddelere geçerli ve güvenilir cevap verdiklerini göstermektedir. 


\section{Örgütsel Özdeşleşme Ölçeği}

Çalışanların örgütsel özdeşleşme düzeylerinin belirlenmesi amacıyla Mael ve Ashforth (1992) tarafından geliştirilen, Tüzün (2006) tarafından Türkçeye uyarlanan Örgütsel Özdeşleşme Ölçeği kullanılmıştır. Ölçekte tek boyutta toplanan 6 madde yer almaktadır. Maddelere verilecek cevaplar 5'li Likert tipinde derecelendirilmiş olup 1-Kesinlikle Katılmıyorum, 5Kesinlikle Katılıyorum ifadesini belirtmektedir. Ölçekte yer alan maddelerin tamamı olumlu özellik göstermektedir. Ölçekten alınan yüksek puanlar, kişilerin örgütsel özdeşleşmelerinin yüksek; düşük puanlar düşük olduğunu göstermektedir.

Ölçeğin orijinalinde ölçek maddelerine verilen cevapların iç tutarlılık Cronbach alfa güvenirlik katsayısı 0,87 (Mael ve Ashforth, 1992), Türkçe uygulamasında 0,78 olarak hesaplanmıştır.

$\mathrm{Bu}$ araştırmada çalışanların örgütsel özdeşleşme düzeylerinin belirlenmesi amacıyla öncelikle ölçeğin 6 maddeden ve tek boyuttan oluşan düzenine ilişkin ölçme modeli kurulmuş, hesaplanan model-veri uyum değerleri Tablo 2'de gösterilmiştir.

Tablo 2. Örgütsel Özdeşleşme Ölçeğine İlişkin Ölçme Modeline Ait Uyum İndeks Değerleri

\begin{tabular}{ccccc}
\hline $\begin{array}{c}\text { Uyum } \\
\text { Indeks }\end{array}$ & $\begin{array}{c}\text { Oluşturulan } \\
\text { Model Değerleri }\end{array}$ & $\begin{array}{c}\text { Mükemmel Uyum } \\
\text { Kriterleri }\end{array}$ & $\begin{array}{c}\text { Kabul Edilebilir Uyum } \\
\text { Kriterleri }\end{array}$ & Değerlendirme \\
\hline$\chi 2 /(\mathrm{df})$ & $\begin{array}{c}16,01(9) \\
=1,78\end{array}$ & $0 \leq \chi^{2} \leq 3$ & $3<\chi^{2} \leq 5$ & Mükemmel uyum \\
RMSEA & 0,062 & $0 \leq \mathrm{RMSEA} \leq 0,05$ & $0,05<\mathrm{RMSEA} \leq 0,08$ & Mükemmel uyum \\
CFI & 0,99 & $0,97 \leq \mathrm{CFI} \leq 1,00$ & $0,95 \leq \mathrm{CFI}<0,97$ & Mükemmel uyum \\
NFI & 0,99 & $0,95 \leq \mathrm{NFI} \leq 1,00$ & $0,90 \leq \mathrm{NFI}<0,95$ & Mükemmel uyum \\
AGFI & 0,94 & $0,90 \leq \mathrm{AGFI} \leq 1,00$ & $0,85 \leq \mathrm{AGFI}<0,90$ & Mükemmel uyum \\
GFI & 0,97 & $0,95 \leq \mathrm{GFI} \leq 1,00$ & $0,90 \leq \mathrm{GFI}<0,95$ & Mükemmel uyum \\
\hline
\end{tabular}

Tablo-2'deki bilgiler incelendiğinde Kayseri ili organize sanayi bölgesinde faaliyette bulunan işletmelerdeki çalışanların örgütsel özdeşleşme düzeylerinin tek boyutlu 6 maddelik modelinin -hesaplanan model-veri uyum değerleri doğrultusunda ( $\chi^{2 /}$ (df), RMSEA, CFI, NFI, AGFI ve GFI)- mükemmel düzeyde uyum gösterdiği belirlenmiştir (Schermelleh-Engel, Moosbrugger, Müller, 2003). Ayrıca çalışanların ölçek maddelerine vermiş oldukları cevapların Cronbach alfa güvenirlik katsayısı 0,901 olarak hesaplanmıştır. Başka bir anlatımla özel sektör çalışanları örgütsel özdeşleşme ölçeğindeki maddelere, geçerli ve güvenilir düzeyde cevap vermişlerdir.

İssten Ayrılma Niyeti Ölçeği

Araştırma kapsamında görüşleri alınan çalışanların işten ayrılma niyetlerinin belirlenmesi amacıyla Scott ve arkadaşları (1999) tarafından geliştirilen Tanrıöver (2005) tarafından Türkçe uyarlaması yapılan İşten Ayrılma Niyeti ölçeği kullanılmıştır. Ölçekte tek boyutta toplanan 4 madde bulunmaktadır. Maddeler 1-Kesinlikle Katılmıyorum, 5-Kesinlikle Katılıyorum olmak üzere 5'li Likert tipinde derecelendirilmiştir. Ölçekten alınan yüksek puanlar, kişilerin işten ayrılma niyetlerinin de yüksek olduğunu ifade etmektedir. Tanrıöver (2005), işten ayrılma niyeti ölçeğindeki maddelere verilen cevapların Cronbach alfa güvenirliğini 0,711 olarak hesaplamıştır (Tanrı̈̈ver, 2005). 
$\mathrm{Bu}$ araştırma kapsamında anket uygulanan çalışanların işten ayrılma niyetleri de ölçülmüş, öncelikle ölçeğin tek boyutlu 4 maddelik formu ölçme modeliyle test edilmiştir. Hesaplanan model-veri uyum değerleri Tablo 3’te gösterilmiştir.

Tablo 3. Isşten Ayrılma Niyeti Ölçeğine İlişkin Ölçme Modeline Ait Uyum İndeks Değerleri

\begin{tabular}{ccccc}
\hline $\begin{array}{c}\text { Uyum } \\
\text { Indeks }\end{array}$ & $\begin{array}{c}\text { Oluşturulan } \\
\text { Model Değerleri }\end{array}$ & $\begin{array}{c}\text { Mükemmel Uyum } \\
\text { Kriterleri }\end{array}$ & $\begin{array}{c}\text { Kabul Edilebilir Uyum } \\
\text { Kriterleri }\end{array}$ & Değerlendirme \\
\hline$\chi^{2 /(\mathrm{df})}$ & $\begin{array}{c}2,02(2) \\
=1,01\end{array}$ & $0 \leq \chi^{2} \leq 3$ & $3<\chi^{2} \leq 5$ & Mükemmel uyum \\
RMSEA & 0,007 & $0 \leq \mathrm{RMSEA} \leq 0,05$ & $0,05<\mathrm{RMSEA} \leq 0,08$ & Mükemmel uyum \\
CFI & 0,99 & $0,97 \leq \mathrm{CFI} \leq 1,00$ & $0,95 \leq \mathrm{CFI}<0,97$ & Mükemmel uyum \\
NFI & 0,99 & $0,95 \leq \mathrm{NFI} \leq 1,00$ & $0,90 \leq \mathrm{NFI}<0,95$ & Mükemmel uyum \\
AGFI & 0,97 & $0,90 \leq \mathrm{AGFI} \leq 1,00$ & $0,85 \leq \mathrm{AGFI}<0,90$ & Mükemmel uyum \\
GFI & 0,99 & $0,95 \leq \mathrm{GFI} \leq 1,00$ & $0,90 \leq \mathrm{GFI}<0,95$ & Mükemmel uyum \\
\hline
\end{tabular}

Tablo-3 incelendiğinde çalışanların işten ayrılma niyetlerinin tek boyutlu 4 maddelik modelinin - hesaplanan model-veri uyum değerleri doğrultusunda ( $\chi 2$ / (df), RMSEA, CFI, NFI, AGFI ve GFI)- mükemmel düzeyde uyum gösterdiği belirlenmiştir (Byrne, 2013; Schermelleh-Engel, Moosbrugger, Müller, 2003). Benzer şekilde anket uygulanan çalışanların ölçek maddelerine vermiş oldukları cevaplar doğrultusunda Cronbach alfa güvenirlik katsayısı hesaplanmış ve 0,917 olarak bulunmuştur. Diğer bir ifadeyle özel sektör çalışanlarının işten ayrılma niyetleri ölçeğine geçerli ve güvenilir cevap verdikleri saptanmıştır.

\section{Verilerin Analizi}

Araştırma kapsamında toplanan veriler öncelikle SPSS-21 istatistik programına işlenmiştir, ardından eksik ve /veya hatalı veri olup olmadığı incelenmiştir. Tek değişkenli uç değer incelemesi için $\mathrm{z}$ istatistiğinden yararlanılmış ve ölçek puanlarının $\mathrm{z}$ değerlerinin \pm 3 arasında değer aldığı belirlenmiştir. Çok değişkenli uç değer hesaplaması amacıyla da Mahalanobis uzaklığı hesaplanmıştır. Veri setlerinin dağılımlarının incelenmesi için önce basıklık-çarpıklık katsayısı hesaplanmış, ardından histogram grafikleri oluşturulmuş, sonuçlar Tablo 4 'te ve Şekil 4’te gösterilmiştir.

Tablo 4. Ölçeklerden alınan puanların çarpıklık-basıklık katsayıları

\begin{tabular}{lccc}
\hline Ölçekler & $\mathbf{N}$ & Çarpıklık & Basıklık \\
\hline Duygusal bağl1lık & 232 & $-0,216$ & 0,910 \\
\hline Zorunluluk bağlılı̆̆ & 232 & $-0,683$ & 0,783 \\
\hline Devam bağl1lı̆̆ı & 232 & $-0,108$ & 0,183 \\
\hline Örgütsel bağlılık & 232 & $-0,562$ & 0,198 \\
\hline Örgütsel özdeşleşme & 232 & $-0,728$ & 0,066 \\
\hline İșten ayrılma niyeti & 232 & 0,457 & $-0,962$ \\
\hline
\end{tabular}


Tablo 4'te yer alan bilgiler incelendiğinde çalışanların ölçeklerden aldıkları puanların çarpıklık ve basıklık katsayılarının \pm 1 arasında değer aldığı görülmektedir. Başka bir anlatımla çalışanların ölçek puanlarının genel olarak normal dağılım gösterdiği, normallikten aşırı bir sapma göstermediği tespit edilmiştir (Büyüköztürk, 2018).

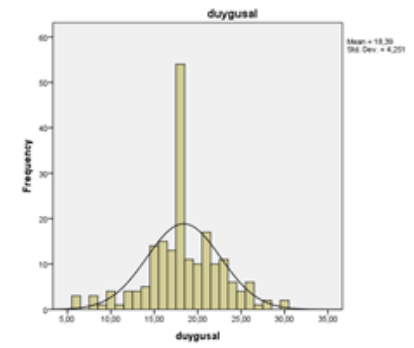

Duygusal bağlilık

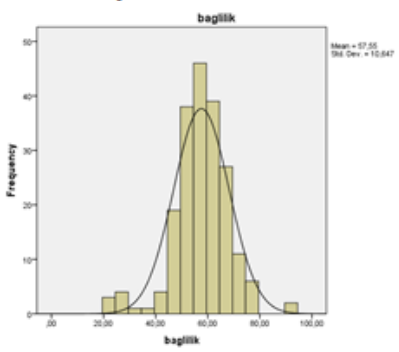

Örgütsel bağlılık

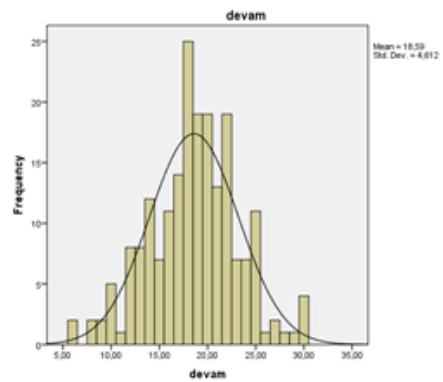

Devam bağlilığ

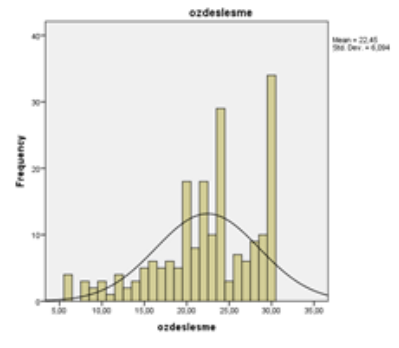

Örgütsel özdeșleșme

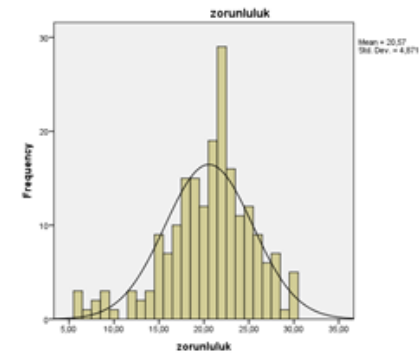

Zorunluluk bağlılığ

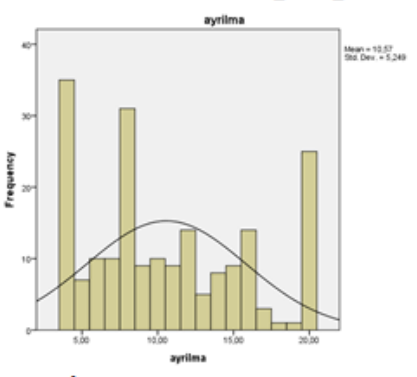

İșten ayrılma niyeti

\section{Şekil 4. Ölçeklerden alınan puanların dağılımına ilişkin oluşturulan histogram grafikleri}

Ölçeklerden alınan puanların normal dağılım gösterdiği belirlendikten sonra verilerin çözümlenmesi sürecinde öncelikle betimsel istatistikler hesaplanmıştır. Ardından da Kayseri ili organize sanayi bölgesinde faaliyette bulunan işletmelerdeki çalışanların örgütsel bağlılık, örgütsel özdeşleşme ve işten ayrılma niyetleri arasındaki ilişkiyi belirlemeye yönelik yapısal eşitlik modellemesi oluşturulmuştur.

\section{Bulgular ve Yorum}

Betimsel istatistikler

Kayseri ili organize sanayi bölgesinde faaliyette bulunan işletmelerdeki çalışanların örgütsel bağll1ık, örgütsel özdeşleşme ve işten ayrılma niyetlerinin tespit edilmesi amacıyla minimum, maksimum, ortalama ve standart sapma değerlerini içeren betimsel istatistikler hesaplanmış, sonuçlar Tablo 5’te gösterilmiştir. 
Tablo 5. Ölçeklerden alınan puanların betimsel istatistikleri

\begin{tabular}{lccccc}
\hline \multicolumn{1}{c}{ Ölçekler } & $\mathbf{N}$ & Minimum & Maksimum & $\overline{\boldsymbol{X}}$ & $\mathbf{S}_{\mathbf{x}}$ \\
\hline Duygusal bağlılık & 232 & 6,00 & 30,00 & 18,39 & 4,25 \\
\hline Zorunluluk bağl1lı̆̆ & 232 & 6,00 & 30,00 & 20,57 & 4,87 \\
\hline Devam bağlılı̆̆1 & 232 & 6,00 & 30,00 & 18,59 & 4,61 \\
\hline Örgütsel bağl1lık & 232 & 22,00 & 90,00 & 57,55 & 10,65 \\
\hline Örgütsel özdeşleşme & 232 & 6,00 & 30,00 & 22,45 & 6,09 \\
\hline İşten ayrılma niyeti & 232 & 4,00 & 20,00 & 10,57 & 5,25 \\
\hline
\end{tabular}

Tablo 5 incelendiğinde Kayseri ili organize sanayi bölgesinde faaliyette bulunan işletmelerdeki duygusal bağlılık düzeylerinin 6,00 ile 30,00 puan arasında değişiklik gösterdiği belirlenmiştir. Çalışanların duygusal bağlılık puanlarının ortalaması 18,39 $( \pm 4,25)$ olarak hesaplanmıştır. Çalışanların zorunluluk bağlılıklarının da 6,00 ile 30,00 arasında farklılık gösterdiği, ortalamasının 20,57 $( \pm 4,87)$ olarak hesaplandığı tespit edilmiştir. Araştırmaya katılan çalışanların devam bağlılıklarının 6,00 ile 30,00 arasında değiştiği, ortalamasının 18,59 $( \pm 4,61)$ olarak hesaplandığı tespit edilmiştir. Çalışanların duygusal, zorunluluk ve devam bağlılıklarının genel olarak orta düzeyde olduğu, çalışanların en yüksek bağlllıklarının zorunluluk olduğu tespit edilmiştir.

Özel sektör çalışanlarının örgütsel bağlılık puanlarının 22,00 ile 90,00 arasında farklılık gösterdiği, ortalamasının 57,55 ( $\pm 10,65)$ olarak hesaplandığı belirlenmiştir. Araştırmaya katılan çalışanların örgütsel bağlılıklarının genel olarak orta düzeyde olduğu saptanmıştır.

Çalışanların örgütsel özdeşleşme düzeylerine ilişkin puanların 6,00 ile 30,00 arasında farklılık gösterdiği, ortalamasının 22,45 ( $\pm 6,09)$ olarak hesaplandığı tespit edilmiştir. Başka bir ifadeyle özel sektör çalışanlarının örgütsel özdeşleşme düzeylerinin genel olarak yüksek düzeyde olduğu belirlenmiştir.

Araştırmaya katılan çalışanların işten ayrılma niyetlerine ilişkin puanların 4,00 ile 20,00 arasında değişiklik gösterdiği, ortalamasının 10,57 $( \pm 5,25)$ olarak hesaplandığı belirlenmiştir. Çalışanların işten ayrılma niyetlerinin genel olarak düşük düzeyde olduğu belirlenmiştir.

\section{Yapısal eşitlik modellemesi sonuçları}

Kayseri ili organize sanayi bölgesinde faaliyette bulunan işletmelerdeki çalışanların örgütsel bağlllık, örgütsel özdeşleşme ve işten ayrılma niyetleri arasındaki ilişkilerin tespit edilmesi amacıyla yapısal eşitlik modellemesinden yararlanmış, araştırma kapsamında oluşturulan modelin hesaplama sonuçları Şekil 5’te gösterilmiştir. 


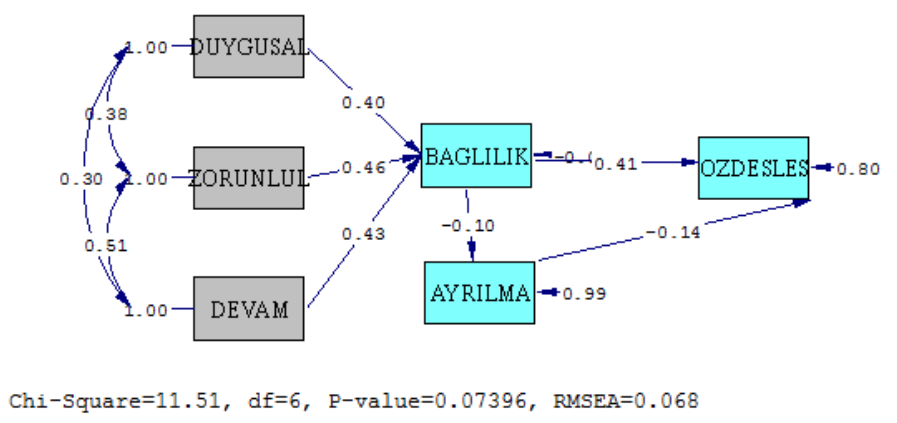

\section{Şekil 5. Çalışanların örgütsel bağlılık, örgütsel özdeşleşme ve işten ayrılma niyetleri arasındaki ilişkilere yönelik kurulan yapısal eşitlik modellemesi hesaplama sonuçları}

Şekil 5’te yer alan modele ilişkin hesaplanan model-veri uyum değerleri Tablo 6'da gösterilmiştir.

Tablo 6. Yapısal Eşitlik Modeline İlişkin Uyum İndeks Değerleri

\begin{tabular}{ccccl}
\hline $\begin{array}{c}\text { Uyum } \\
\text { Indeks }\end{array}$ & $\begin{array}{c}\text { Yapısal Eşitlik } \\
\text { Modeli }\end{array}$ & $\begin{array}{c}\text { Mükemmel Uyum } \\
\text { Kriterleri }\end{array}$ & $\begin{array}{c}\text { Kabul Edilebilir Uyum } \\
\text { Kriterleri }\end{array}$ & Değerlendirme \\
\hline$\chi^{2 /(\mathrm{df})}$ & $\begin{array}{c}13,31(6) \\
=2,22\end{array}$ & $0 \leq \chi^{2} \leq 3$ & $3<\chi^{2} \leq 5$ & Mükemmel uyum \\
RMSEA & 0,068 & $0 \leq \mathrm{RMSEA} \leq 0,05$ & $0,05<\mathrm{RMSEA} \leq 0,08$ & Kabul edilebilir uyum \\
CFI & 0,99 & $0,97 \leq \mathrm{CFI} \leq 1,00$ & $0,95 \leq \mathrm{CFI}<0,97$ & Mükemmel uyum \\
NFI & 0,98 & $0,95 \leq \mathrm{NFI} \leq 1,00$ & $0,90 \leq \mathrm{NFI}<0,95$ & Mükemmel uyum \\
AGFI & 0,93 & $0,90 \leq \mathrm{AGFI} \leq 1,00$ & $0,85 \leq \mathrm{AGFI}<0,90$ & Mükemmel uyum \\
GFI & 0,98 & $0,95 \leq \mathrm{GFI} \leq 1,00$ & $0,90 \leq \mathrm{GFI}<0,95$ & Mükemmel uyum \\
\hline
\end{tabular}

Tablo 6'ya bakıldığında araştırma kapsamında oluşturulan yapısal eşitlik modellemesinin model-veri uyum değerlerinin ( $\chi 2$ / (df), NFI, AGFI ve GFI)- mükemmel düzeyde, RMSEA değerinin kabul edilebilir düzeyde uyum gösterdiği belirlenmiştir (Schermelleh-Engel, Moosbrugger, Müller, 2003).

Araştırma kapsamında ilk olarak çalışanların örgütsel bağlılık düzeyleri ile örgütsel özdeşleşme $(\beta=0,428 ; \mathrm{p}<0,05)$ ve işten ayrılma niyetleri arasında $(\beta=-0,158 ; \mathrm{p}<0,05)$ arasında anlamlı ilişkilerin olduğu; benzer şekilde örgütsel özdeşleşme düzeyleri ile işten ayrılma niyetleri arasında da $(\beta=-0,176 ; p<0,05)$ anlamlı bir ilişkinin olduğu tespit edilmiştir. Bu nedenle bağımsız değişkenin bağımlı değişkenleri etkilediği söylenebilir. Bu doğrultuda araştırma kapsamında işten ayrılma niyetinin aracı değişken olarak incelendiği ve sonuçları Şekil 5'te incelendiğinde; çalışanların örgütsel bağlılıkları ile işten ayrılma niyetleri arasındaki doğrudan ilişkisinin anlamlı olduğu tespit edilmiştir $(\beta=-0,10 ; p<0,05)$. Bağımsız değişken olan örgütsel bağlılığın aracı değişkeni negatif yönde ve düşük düzeyde etkilediği görülmektedir. Aracı değişken işten ayrılma niyeti ile örgütsel özdeşleşme düzeyi arasında da doğrusal ilişkinin istatistiki olarak anlamlı olduğu belirlenmiştir $(\beta=-0,14 ; \mathrm{p}<0,05)$. Bu nedenle aracı değişkenin de örgütsel özdeşleşmeyi negatif yönde ve düşük düzeyde etkilediği görülmektedir. Bu nedenle son olarak psikolojik sermaye ile tükenmişliğin alt boyutları arasındaki ilişkilerde psikolojik ve 
yapısal güçlendirmenin aracılık rolü test edilmiştir. Başlangıçta örgütsel bağlılık düzeyleri ile örgütsel özdeşleşme arasında hesaplanan katsayının $(\beta=0,428 ; p<0,05)$, işten ayrılma niyeti aracı değişkeni modele eklendiğinde az miktarda düştüğü $(\beta=0,41 ; p<0,05)$ belirlenmiştir. $\mathrm{Bu}$ durum, işten ayrılma aracı değişkeninin hem örgütsel özdeşleşme hem de örgütsel bağlılıkla olan ilişkisinin düşük düzeyde hesaplanmasından kaynaklanmaktadır. Başka bir anlatımla çalışanların örgütsel bağlılıklarının örgütsel özdeşlemelerini pozitif yönde ve orta düzeyde etkilediği; değişkenler arasındaki ilişkide işten ayrılma niyetinin düşük düzeyde bir aracı etkisinin olduğu belirlenmiştir.

\section{Sonuç ve Öneriler}

$\mathrm{Bu}$ araştırma kapsamında çalışanların örgütsel bağlılıklarının örgütsel özdeşleşme düzeylerine olan etkisinde işten ayrılma niyetinin aracı rolünün incelenmesi amaçlanmıştır. Araştırma sürecinde örgütsel bağlılığın örgütsel özdeşleşmeyi pozitif yönde ve orta düzeyde etkilediği belirlenmiştir. Çalışanların işten ayrılma niyetinin ise her iki değişkenle (hem bağımlı hem de bağımsız değişkeni) negatif yönde ve düşük düzeyde bir ilişki içinde olduğu tespit edilmiştir. İşten ayrılma niyeti aracı değişken olarak tanımlandığında çalışanların örgütsel bağlılıklarının örgütsel özdeşleşmelerini açılklama düzeyinde ufak da olsa bir düşüş yaşandığ belirlenmiştir. Çalışanların örgütsel bağlılıklarının örgütsel özdeşleşme düzeylerinin \%20'sini açıkladığı belirlenmiştir.

Araştırma kapsamında çalışanların iş sektörlerinde psikolojik ve bilişsel süreçlerini kapsayan örgütsel özdeşleşme düzeylerini artırabilmek için örgütsel bağlılıklarının dikkate alınması ve arttırıcı eylemlerde bulunulması önerilebilir. Aynı zamanda çalışanların örgütsel bağlılıklarını iş akışına göre belirli periyotlar ile gözlemleyerek artırıcı önlemler alınması gerekebilir. Bunun için eğitim seminerleri, kaynaşma ve bilinçlendirme etkinlikleri, sosyal faaliyetler gibi etkinlikler ile aidiyet duygusunu arttırarak bu duygunun davranışa ve tutuma olumlu yansıması sağlanabilir. Çalışanların işten ayrılma niyetleri örgütsel özdeşleşme üzerinde çok fazla etkili bir değişken olmasa da dikkate alınması gereken bir özellik olarak düşünülerek bu niyetlerinin kaynakları araştırılarak giderilmeye çalışılabilir. Gelecekte özel sektörde olduğu gibi kamu sektöründe ve hizmet sektöründe de bu ve benzeri çalışmaların yapılmasının örgütsel davranış literatürüne katkı sağlayacaktır. Araştırma maliyet ve ulaşım problemleri nedeni ile kısıtlı kalmıştır. İleride farklı sektörlerde ve farklı cinsiyet bileşenlerine bu çalışmanın uygulanması farklı sonuçları da beraberinde getirebilecektir.

\section{Kaynakça}

Akyüz, M. \& Y1lmaz, F.D. (2015). Konaklama işletmelerinde örgütsel özdeşleşme ve örgütsel iletişimin çalışanların işten ayrılma niyetine etkisi. Kastamonu Üniversitesi İktisadi ve İdari Bilimler Fakültesi Dergisi, 8(2), 138-143.

Allen, N.J. \& Meyer, J.P. (1990). The measurement and antecedents of affective, continuance and normative commitment to the organization, Journal of Occupational Psychology, 63(1), 1-18. 
Balay, R. (2000). Yönetici ve ögrretmenlerde örgütsel bağlılık. Ankara: Nobel.

Byrne, B.M. (2013). Structural equation modeling with LISREL, PRELIS, and SIMPLIS: Basic concepts, applications, and programming. Psychology Press.

Büyüköztürk, Ş. (2018). Sosyal bilimler için veri analizi el kitabı. Ankara: Pegem Akademi.

Cole, M.S. \& Bruch, H. (2006). Organizational identity strength, identification, and commitment and their relationships to turnover intention: Does organizational hierarchy matter?. Journal of Organizational Behavior: The International Journal of Industrial, Occupational and Organizational Psychology and Behavior, 27(5), 585-605.

Çetin, M.Ö. (2004). Örgüt kültürü ve örgütsel bă̆lllık. Ankara: Nobel.

Çınar, C. (2015). Kadınların kariyer engelleri ile örgütsel bağlılıkları arasındaki ilişkinin incelenmesi: Bankacılık sektörü üzerine bir araştırma. (Yayımlanmamış Yüksek Lisans Tezi), Atatürk Üniversitesi, Sosyal Bilimler Enstitüsü, Erzurum.

Demirel, Y. (2008). Örgütsel güvenin örgütsel bağlılık üzerine etkisi: Tekstil sektörü çalışanlarına yönelik bir araştırma, Celal Bayar Üniversitesi İ.I.B.F. Yönetim ve Ekonomi Dergisi, 15(2), 179-194.

Dinçer, N. Ü. (2010). Hemşirelerin işyeri şiddetine maruz kalma durumları ile iş doyumları ve işten ayrılma eğilimleri. (Yayımlanmamış Doktora Tezi), Hacettepe Üniversitesi, Sağlık Bilimleri Enstitüsü, Ankara.

Edwards, M. R. (2005). Organizational identification: A conceptual and operational review. International Journal of Management Reviews, 7(4), 207-230.

Fraenkel, J.R., Wallen, N.E. \& Hyun H.H. (2012). How to design and evaluate research in education (8th edt.), New York: McGram-Hill Companies.

Karasar, N. (2003). Bilimsel araştırma yöntemi. Ankara: Nobel.

Ketchand, A.A. \& Strawser, J.R. (2001). Multiple dimensions of organizational commitment: Implications for future accounting research. Behavioral Research in Accounting, 13(1), 221-251.

Mael, F. \& Ashforth, B.E. (1992). Alumni and their alma mater: A partial test of the reformulated model of organizational identification. Journal of Organizational Behavior, 13(2), 103-123.

Mael, F.A. \& Ashforth, B.E. (1995). Loyal from day one: Biodata, organizational identification, and turnover among newcomers. Personnel Psychology, 48(2), 309-333.

Meyer, J.P. \& Allen N.J. (1991). A three-component conceptualization of organizational commitment, Human Resource Management Review, 1(1), 61-89.

Öktem, Ş., Kızıltan, B. \& Öztoprak, M. (2016). Örgütsel güven ile örgüt ikliminin örgütsel özdeşleşme, iş tatmini ve işten ayrılma niyeti üzerine etkileri: Otel işletmelerinde bir uygulama. Journal of Business Research Turk, 8(4), 162-186.

Riketta, M. (2005). Organizational identification: A meta-analysis. Journal of Vocational Behavior, 66(2), 358-384. 
Schermelleh-Engel, K., Moosbrugger, H. \& Müller, H. (2003). Evaluating the fit of structural equation models: Tests of significance and descriptive goodness-of-fit measures. Methods of Psychological Research Online, 8(2), 23-74.

Schweiger, D.M. \& Denisi, A.S. (1991). Communication with employees following a merger: A longitudinal field experiment. Academy of Management Journal, 34(1), 110-135.

Scott, C.R., Connaughton, S.L., Diaz-Saenz, H.R., Maguire, K., Ramirez, R., Richardson, B. \& Morgan, D. (1999). The impacts of communication and multiple identifications on intent to leave: A multimethodological exploration. Management Communication Quarterly, 12(3), 400-435.

Sökmen, A. \& Şimşek, T. (2017). Örgütsel bağl1lık, örgütle özdeşleşme, stres ve işten ayrılma niyeti ilişkisi: Bir kamu kurumunda araştırma. Gazi Üniversitesi İktisadi ve İdari Bilimler Fakültesi Dergisi, 18(3), 606-620.

Tanrı̈ver, U. (2005). The effects of learning organization climate and self directed learning on job satisfaction, affective commitment and intention to turnover. (Yayımlanmamış Yüksek Lisans Tezi). Marmara Üniversitesi, Sosyal Bilimler Enstitüsü, İstanbul.

Tolukan, E., Şahin, M.Y. \& Koç, M. (2016). Cimnastik antrenörlerinin örgütsel özdeşleşme düzeyleri ve işten ayrılma niyeti ilişkisi. Electronic Turkish Studies, 11(8), 377-398.

Tuna, M. \& Yeşiltaş, M. (2014). Etik iklim, işe yabancılaşma ve örgütsel özdeşleşmenin işten ayrılma niyeti üzerindeki etkisi: Otel işletmelerinde bir araştırma. Anatolia: Turizm Araştırmaları Dergisi, 25(1), 105-117.

Tüzün, İ.K. (2006). Örgütsel güven, örgütsel kimlik ve örgütsel özdeşleşme ilişkisi; uygulamalı bir çalışma. (Yayımlanmamış Doktora Tezi). Gazi Üniversitesi, Sosyal Bilimler Enstitüsü, Ankara. 